CZASOPISMO INŻYNIERII LA¿DOWEJ, ŚRODOWISKA I ARCHITEKTURY JOURNAL OF CIVIL ENGINEERING, ENVIRONMENT AND ARCHITECTURE JCEEA, t. XXXIII, z. 63 (2/I/16), kwiecień-czerwiec 2016, s. 43-56

\author{
Marek GOSZTYLA ${ }^{1}$ \\ Tomasz GOSZTYŁA ${ }^{2}$
}

\title{
WSPÓŁCZESNA ARCHITEKTURA RZESZOWA W OPINIACH OSÓB MIESZKAJĄCYCH I STUDIUJĄCYCH W RZESZOWIE
}

\begin{abstract}
Celem badań było poznanie opinii osób mieszkających i studiujących w Rzeszowie, odnośnie nowych budowli i rozwiązań architektonicznych powstających w obrębie, jak również otulinie zespołu staromiejskiego. W ostatnim czasie obserwuje się liczne dyskusje, toczone na różnych forach, na temat zachowania historycznych wartości zespołów starych miast. Wśród rodzących się pytań, często na plan pierwszy wysuwana jest problematyka współistnienia nowoczesnej architektury w miejskich zespołach zabytkowych. $Z$ uwagi na to, przeprowadzone badania o charakterze sondażowym, miały również na celu przybliżyć opinię mieszkańców Rzeszowa na temat działań związanych z zachowaniem dziedzictwa wielokulturowego, odkrywanego na terenie miasta. Respondenci wskazywali obiekty architektoniczne wybudowane w okresie ostatnich pięciu lat i oceniali ich formę architektoniczną, funkcję oraz zharmonizowanie tych budowli z otoczeniem. Badania dowiodły, że mieszkańcy są zainteresowani nowymi rozwiązaniami architektoniczno - urbanistycznymi w Rzeszowie, potrafią dokonywać ich oceny w zaproponowanej skali, stanowczo opowiadają się za zachowaniem zabytkowego oblicza zespołu miejskiego. W projektowanych nowych kwartałach zabudowy są za utrzymaniem tradycyjnej roli ulic i placów. Popierają prowadzenie badań mających na celu odkrywanie wspólnego dziedzictwa wielokulturowego społeczności i narodów mieszkających przez wiele wieków w Rzeszowie. Akceptują współczesne formy ekspozycji zabytkowych dzieł architektonicznych. Krytycznie badani odnieśli się do budowania w zespole historycznym miasta obiektów powyżej pięciu kondygnacji oraz wielokondygnacyjnych garaży. W sprawie skali rozwoju miasta wskazali na swobodny rozwój ośrodka miejskiego. Badani mieszkańcy wyrazili chęć przedstawiania własnej opinii na temat nowoczesnej architektury realizowanej w miejscu zamieszkania. Wśród przyszłościowych inwestycji architektoniczno- budowlanych, potrzebnych dla rozwoju miasta, na plan pierwszy wysunięto rozwiązania komunikacyjne.
\end{abstract}

Słowa kluczowe: Rzeszów, architektura, dziedzictwo kulturowe, opinia społeczna

\footnotetext{
${ }^{1}$ Autor do korespondencji / corresponding author: Marek Gosztyła, Politechnika Rzeszowska, Zakład Konserwacji Zabytków, Al. Powstańców Warszawy 12, 35-959 Rzeszów; tel. 178651041; gosztyla@prz.edu.pl

2 Tomasz Gosztyła, Uniwersytet Rzeszowski, Zakład Psychologii, ul. Ks. Jałowego 24, 35-010 Rzeszów; tel. 178721883; tomgosz@ur.edu.pl
} 


\section{Wprowadzenie}

Rzeszów cieszy się opinią ośrodka dynamicznie rozwijającego się. W działaniach promujących miasto, konsekwentnie podkreśla się jego rozwój i innowacyjność. Celem niniejszych badań było poznanie opinii osób mieszkających i studiujących w Rzeszowie, odnośnie nowych budowli i rozwiązań architektonicznych powstających $\mathrm{w}$ mieście, a także ich zharmonizowania $\mathrm{z}$ istniejącą zabudową. Niniejszy projekt wpisuje się w badania prowadzone na Podkarpaciu od sześciu lat, a dotyczące opinii mieszkańców takich ośrodków jak Rzeszów, Jarosław i Przemyśl, odnośnie działań konserwatorskich i urbanistycznych, podejmowanych na ich terenie $[1,2]$.

\section{Opis procedury badawczej}

Problematyka badawcza podjęta w niniejszym opracowaniu wyraża się w następujących pytaniach:

- jaka jest opinia osób, które mieszkają i studiują w Rzeszowie, na temat nowo powstających budowli i nowych rozwiązań architektonicznych w mieście?

- jak oceniane są te obiekty pod względem funkcjonalności, formy architektonicznej oraz zharmonizowania z otoczeniem?

- jak oceniane są działania architektoniczne w obrębie zabytkowego miasta?

Badania miały charakter wstępnego sondażu opinii i zrealizowano je w miesiącu maju i czerwcu 2014 r. Wzięło w nich udział 189 osób, w tym: 146 kobiet (77,25\% ogółu badanych) i 43 mężczyzn (22,75\% badanych). Struktura wiekowa respondentów została przedstawiona w Tabeli 1.

Tabela 1. Wiek badanych, źródło: opracowanie własne

Table. 1. Age of the respondents, source: own study

\begin{tabular}{|c|c|c|}
\hline Wiek & L. & \% \\
\hline 19-25 lat & 113 & 59,79 \\
\hline 26-35 lat & 31 & 16,40 \\
\hline 36-45 lat & 26 & 13,76 \\
\hline 46-55 lat & 17 & 8,99 \\
\hline 56-65 lat & 2 & 1,06 \\
\hline
\end{tabular}

W badaniach wykorzystano kwestionariusz ankiety w opracowaniu własnym. Narzędzie składało się z 17 pytań: 15 zamkniętych i 3 otwartych. 


\section{Analiza wyników}

W pierwszym pytaniu ankiety proszono respondentów o wymienienie nowych obiektów, powstałych w Rzeszowie w ciągu ostatnich pięciu lat (a więc w okresie 2009-2014 r.). Rezultaty zebrano w Tabeli 2.

Oprócz obiektów zestawionych w Tabeli 2, poniżej dziesięciu wskazań uzyskały: hotel Rzeszów (5), skatepark przy ul. Podpromie (5), osiedle Słoneczny Stok (4), budynek wielorodzinny przy ul. Kwiatkowskiego (4), biblioteka WSPiA (4), klinika Profamilia (2), droga ekspresowa S19 (2), hotel Bristol (2), osiedla mieszkaniowe Staromieście - Ogrody i Tęczowe Osiedle (2), park papieski (2), obiekty sportowe osiedle Budziwój (2).

Tabela 2. Wymieniane przez respondentów nowe obiekty, powstałe w Rzeszowie w ciągu ostatnich pięciu lat, źródło: opracowanie własne

Table 2. New objects built in Rzeszów, in the past five years, mentioned by respondents, source: own study

\begin{tabular}{|l|c|}
\hline \multicolumn{1}{|c|}{ Obiekt } & L. \\
\hline Galeria Rzeszów & 177 \\
\hline Kładka nad ul. Piłsudskiego & 138 \\
\hline Galeria Millenium Hall & 122 \\
\hline Centrum Mikroelektroniki i Nanotechnologii UR & 108 \\
\hline Budynek „V” Politechniki Rzeszowskiej & 106 \\
\hline Most Narutowicza & 69 \\
\hline Multimedialna fontanna & 69 \\
\hline Ogrody bernardyńskie & 57 \\
\hline Capital Towers & 57 \\
\hline Sąd Rejonowy, ul. Kustronia & 47 \\
\hline Gmach Urzędu Marszałkowskiego & 13 \\
\hline Galeria „Nowy Świat” & 12 \\
\hline Osiedle Zawiszy, przy ul. Architektów & 11 \\
\hline Terminal lotniska Rzeszów-Jasionka & 10 \\
\hline
\end{tabular}




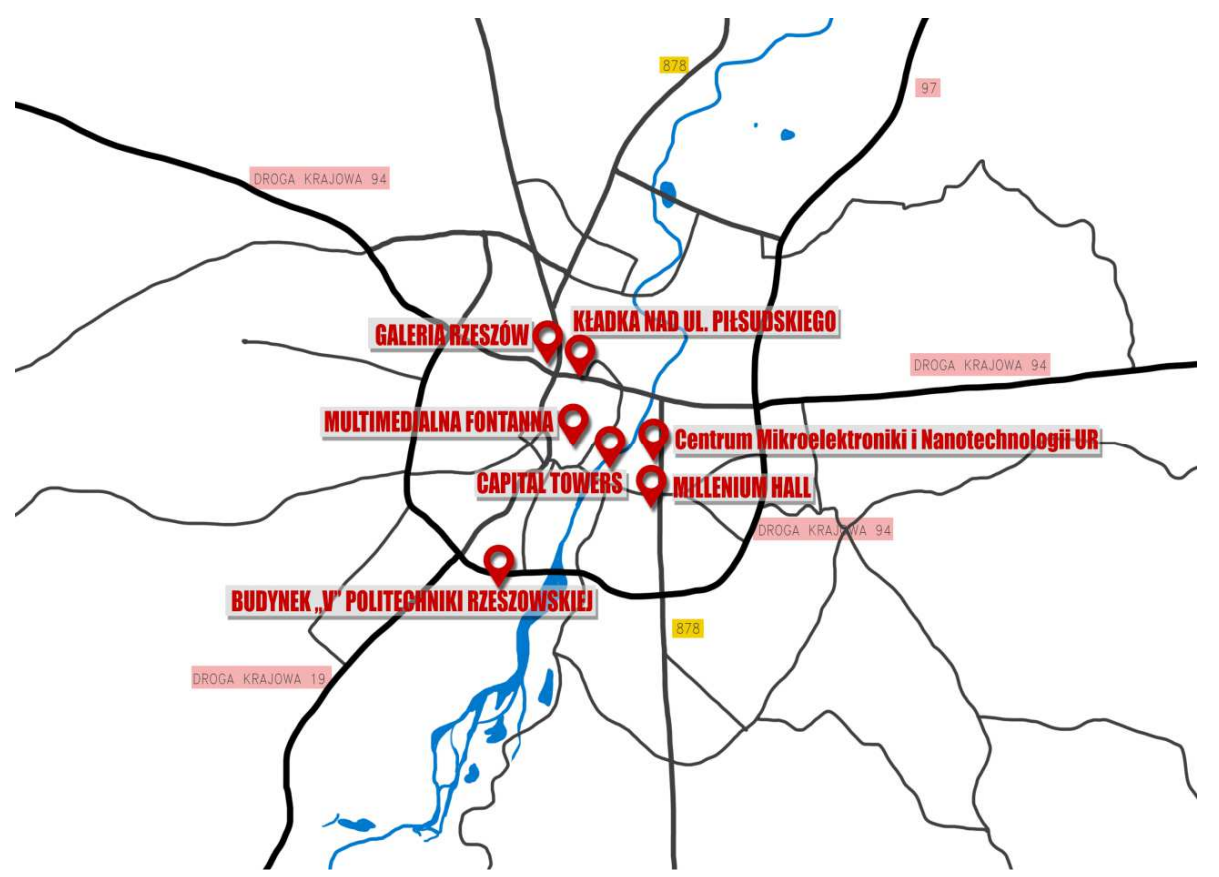

Rys. 1. Lokalizacja badanych obiektów na terenie miasta Rzeszowa, oprac. A. Kumuda

Fig. 1. Localization of the studied objects in the city of Rzeszow, source: A. Kumuda

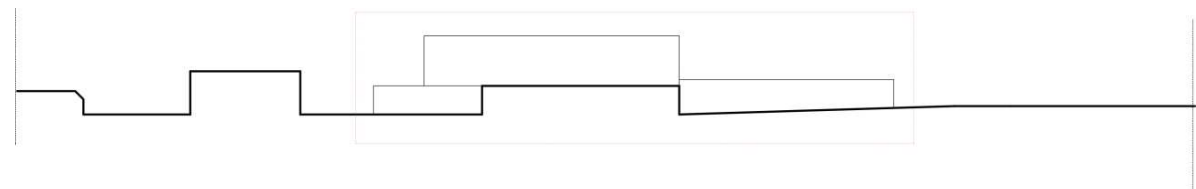

Rys. 2. Galeria Rzeszów, oprac. A. Kumuda

Fig. 2. Rzeszow Shopping Centre, source: A. Kumuda

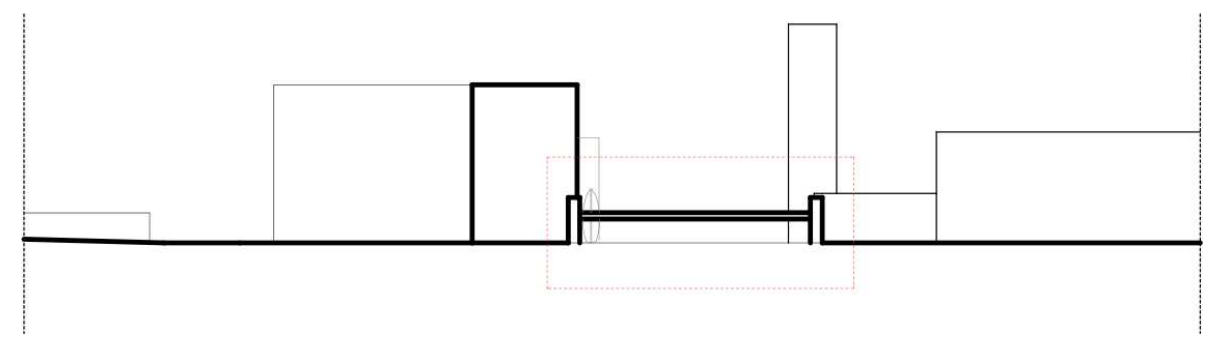

Rys. 3. Kładka nad ul. Piłsudskiego, oprac. A. Kumuda

Fig. 3. Footbridge over the Pilsudskiego Street, source: A. Kumuda 


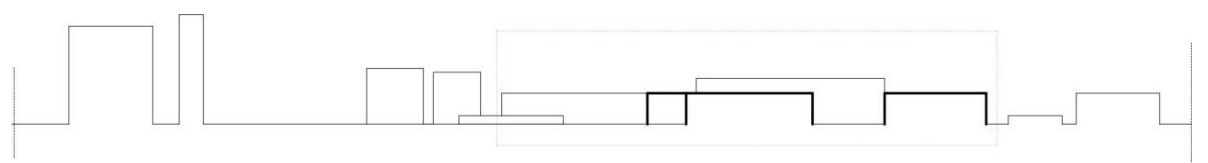

Rys. 4. Galeria Millenium Hall, oprac. A. Kumuda

Fig. 4. Millenium Hall Shopping Centre, source: A. Kumuda

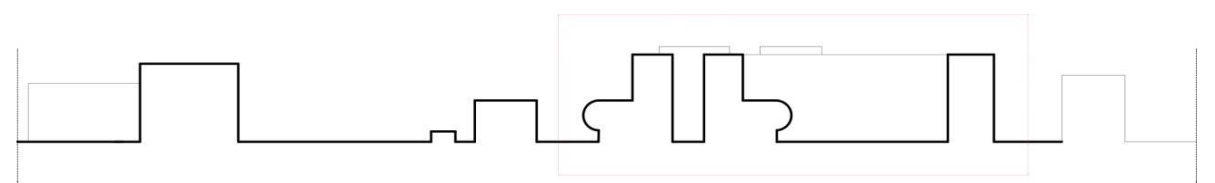

Rys. 5. Centrum Mikroelektroniki i Nanotechnologii UR, oprac. A. Kumuda

Fig. 5. Centre for Microelectronics and Nanotechnology at the University of Rzeszow, source: A. Kumuda

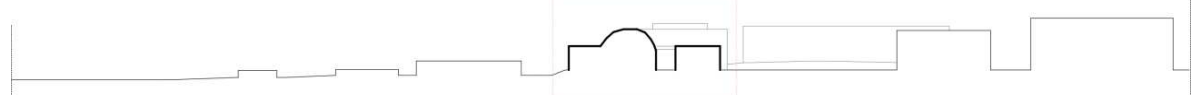

Rys. 6. Budynek „V” Politechniki Rzeszowskiej, oprac. A. Kumuda

Fig. 6. Building V- Regional Centre for Education and Conference and Library and Administration, source: A. Kumuda

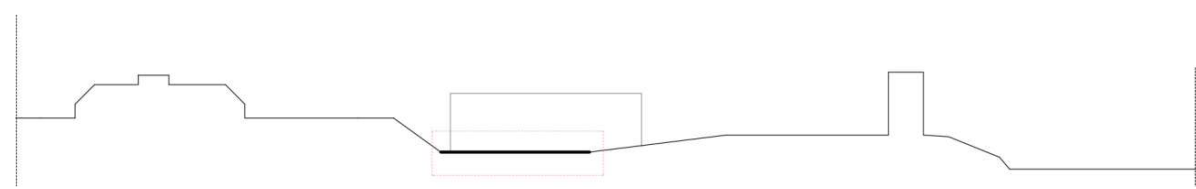

Rys. 7. Multimedialna fontanna, oprac. A. Kumuda

Fig. 7. Multimedia fountain, source: A. Kumuda

Pytanie drugie dotyczyło oceny nowych rozwiązań architektonicznych miasta pod względem funkcjonalności, formy architektonicznej i zharmonizowania $\mathrm{z}$ otoczeniem. Badani dokonywali jej na 5-cio stopniowej skali, gdzie 1 oznaczało ocenę najniższą, a 5 - najwyższą. Średnie wyniki zestawiono w Tabeli 3, dodatkowo ilustruje je Rycina 8.

Tabela 3. Ocena nowych rozwiązań architektonicznych powstałych w Rzeszowie - opinie respondentów, źródło: opracowanie własne

Table 3. Assessment of new architectural solutions in Rzeszów-respondents' opinions, source: own study

\begin{tabular}{|l|c|}
\hline \multicolumn{1}{|c|}{ Aspekt oceny } & Średnia \\
\hline Funkcjonalność & 3,19 \\
\hline Forma architektoniczna & 3,89 \\
\hline Zharmonizowanie z otoczeniem & 3,30 \\
\hline
\end{tabular}




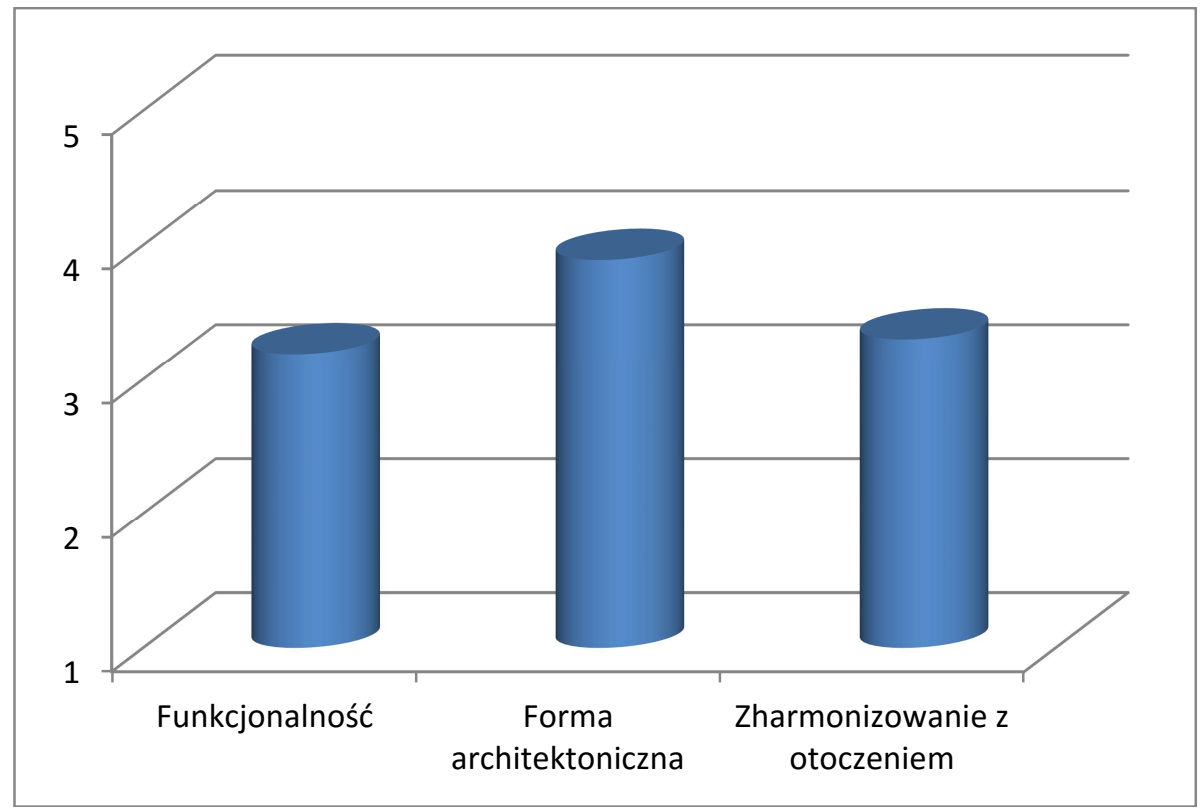

Rys. 8. Średnie ocen nowych rozwiązań architektonicznych powstałych w Rzeszowie, źródło: opracowanie własne

Fig. 8. Average scores of new architectural solutions in Rzeszów, source: own study

W dalszej kolejności pytano respondentów, które z nowo powstałych zabudowań w Rzeszowie można uznać za symbol rozwoju miasta. Najczęściej podawane odpowiedzi zebrano w Tabeli 4.

Oprócz obiektów wyszczególnionych w powyższej tabeli, po jednym wskazaniu zebrały ogrody bernardyńskie (,początek rozwoju w dobrą stronę”) oraz budynek sądu przy ul. Kustronia (,,nowoczesny”).

Respondentów pytano również o to, czy są za prowadzeniem badań zachowanych materialnych wartości kulturowych w Rzeszowie, takich, jak: świątynie, cmentarze i kamienice, a następnie opracowaniem projektów ich ekspozycji. Rozkład uzyskanych odpowiedzi zawarto w Tabeli 5. 
Tabela 4. Nowo powstałe zabudowania w Rzeszowie, które - zdaniem respondentów - można uznać za symbol miasta, źródło: opracowanie własne

Table 4. Newly established buildings in Rzeszów, which in the opinion of the respondents can be considered as a symbol of the city, source: own study

\begin{tabular}{|c|c|c|}
\hline Pozycja & Obiekt & Uzasadnienie \\
\hline 1. & Kładka nad ul. Piłsudskiego & $\begin{array}{l}\text { nowy kierunek w podejściu do uspraw- } \\
\text { nienia komunikacji; bardzo nowoczesna; } \\
\text { interesuje formą i intryguje funkcją; } \\
\text { bezpieczna; punkt orientacyjny miasta }\end{array}$ \\
\hline 2. & $\begin{array}{l}\text { Centrum Mikroelektroniki } \\
\text { i Nanotechnologii UR }\end{array}$ & $\begin{array}{l}\text { ciekawa bryła; funkcjonalny układ; } \\
\text { przemyślana, nowoczesna forma archi- } \\
\text { tektoniczna; przyjazne zagospodarowanie } \\
\text { przestrzeni; świadczy o rozwoju nauko- } \\
\text { wym i poszerzaniu oferty edukacyjnej } \\
\text { miasta; stworzony z rozmachem }\end{array}$ \\
\hline 3. & Galeria Rzeszów & $\begin{array}{l}\text { dominanta w centrum miasta; nowa ja- } \\
\text { kość architektury; bogata oferta spędza- } \\
\text { nia czasu }\end{array}$ \\
\hline 4. & Multimedialna fontanna & $\begin{array}{l}\text { ciekawa, innowacyjna forma; możliwość } \\
\text { miłego i bezpłatnego spędzania czasu } \\
\text { wolnego; unikatowa; nowoczesna }\end{array}$ \\
\hline 5. & $\begin{array}{l}\text { Budynek ,V” Politechniki } \\
\text { Rzeszowskiej }\end{array}$ & $\begin{array}{l}\text { rozwój oferty edukacyjnej miasta; cieka- } \\
\text { wa bryła, funkcjonalny układ; przemy- } \\
\text { ślana forma architektoniczna; zharmoni- } \\
\text { zowany z otoczeniem; budynek reprezen- } \\
\text { tatywny; orientacja na rozwój nauki i } \\
\text { techniki }\end{array}$ \\
\hline 6. & Galeria Millenium Hall & $\begin{array}{l}\text { nowoczesna forma architektoniczna; } \\
\text { wysoka jakość wykończenia; zharmoni- } \\
\text { zowanie z otoczeniem; ożywia tę część } \\
\text { miasta; nowatorska bryła z zastosowa- } \\
\text { niem dziedzińców }\end{array}$ \\
\hline 7. & Capital Towers & $\begin{array}{l}\text { ciekawa i nowoczesna forma architekto- } \\
\text { niczna; pierwsza taka inwestycja } \\
\text { w Rzeszowie; zapoczątkowuje powsta- } \\
\text { wanie budynków wysokościowych; ko- } \\
\text { rzystna kompozycja urbanistyczna; } \\
\text { zharmonizowanie z otoczeniem }\end{array}$ \\
\hline
\end{tabular}


Tabela. 5. Rozkład odpowiedzi na pytanie: Czy jest Pan(i) za prowadzeniem badań zachowanych materialnych wartości kulturowych w Rzeszowie (świątynie cmentarze, kamienice), a nastepnie opracowaniem projektów ich ekspozycji? źródło: opracowanie własne

Table. 5. Responses to the question: Should, according to your opinion, research on preserved historical urban architecture of Rzeszów (temples, cemeteries, buildings) and programme(s) to make it available to visitors be done and (respectively) worked out? source: own study

\begin{tabular}{|l|c|c|}
\hline Decyzja & L. & \% \\
\hline Tak & 162 & 85,71 \\
\hline Nie & 4 & 2,12 \\
\hline Nie mam zdania & 23 & 12,17 \\
\hline
\end{tabular}

Dopełnieniem pytania czwartego było pytanie piąte, które brzmiało: $C z y$ uważa Pan(i), że w rozwiazaniach urbanistycznych i architektonicznych należy eksponować wspólne dziedzictwo kulturowe, jako ślad historycznego sasiedztwa różnych grup narodowych i religijnych zamieszkujacych w Rzeszowie? Rozkład odpowiedzi prezentuje Tabela 6.

Tabela 6. Rozkład odpowiedzi na pytanie: Czy uważa Pan(i), że w rozwiazaniach urbanistycznych i architektonicznych należy eksponować wspólne dziedzictwo kulturowe, jako ślad historycznego sąsiedztwa różnych grup narodowych i religijnych zamieszkujących w Rzeszowie? źródło: opracowanie własne

Table 6. Responses to the question: Do you think that urban and architectural solutions should expose common cultural heritage as remains of historical neighbourhood of various national and religious groups living in Rzeszów? source: own study

\begin{tabular}{|l|c|c|}
\hline Decyzja & L. & \% \\
\hline Tak & 155 & 82,01 \\
\hline Nie & 11 & 5,82 \\
\hline Nie mam zdania & 23 & 12,17 \\
\hline
\end{tabular}

Kolejna kwestia, którą poruszono w badaniach, dotyczyła opinii respondentów na temat tego, czy powinno się zezwalać na budowę wysokich obiektów w zespole staromiejskimi Rzeszowa. Rozkład odpowiedzi badanych zebrano w Tabeli 7.

Tabela 7. Rozkład odpowiedzi na pytanie: Jak Pan(i) sadzi, czy w zespole staromiejskim Rzeszowa powinno się zezwalać na budowę obiektów wysokich (powyżej pięciu kondygnacji)? źródło: opracowanie własne

Table 7. Responses to the question: Do you take the view that construction of tall buildings (of more than five storeys) in the Rzeszów's Old Town Complex should be allowed? source: own study

\begin{tabular}{|l|c|c|}
\hline Decyzja & L. & \% \\
\hline Tak & 37 & 19,58 \\
\hline Nie & 142 & 75,13 \\
\hline Nie mam zdania & 10 & 5,29 \\
\hline
\end{tabular}


Pytanie kolejne brzmiało: Do jakiej skali (liczba ludności) należy planować rozwój Rzeszowa: do 1 mln mieszkańców, do 500 tys. mieszkańców, czy może postawić na swobodny rozwój? Wyniki prezentuje Tabela 8.

Tabela 8. Rozkład odpowiedzi na pytanie: Do jakiej skali (liczba ludności) należy planować rozwój Rzeszowa: do 1 mln mieszkańców, do 500 tys. mieszkańców, czy może postawić na swobodny rozwój? źródło: opracowanie własne

Table 8. Responses to the question: How should we plan the scale of evolution of Rzeszów in terms of the population numbers: should we assume a limit of the population of the city at a level of 0.5 or 1 million or should we set no population limits down? source: own study

\begin{tabular}{|l|c|c|}
\hline Decyzja & L. & \% \\
\hline Do 1 mln mieszkańców & 14 & 7,41 \\
\hline Do 500 tys. mieszkańców & 56 & 29,62 \\
\hline Należy postawić na swobodny rozwój & 92 & 48,68 \\
\hline Nie mam zdania & 27 & 14,29 \\
\hline
\end{tabular}

Respondentów pytano również, czy w obrębie zabytkowego miasta należy planować budowę wielopiętrowych parkingów. Odpowiedzi zestawiono w Tabeli 9 .

Tabela 9. Rozkład odpowiedzi na pytanie: Czy wraz z rozwojem zjawiska „syndromu samochodów" w Rzeszowie należy planować budowę wielopiętrowych parkingów w obrębie zabytkowego miasta? źródło: opracowanie własne

Table 9. Responses to the question: Should multi-storey car parks, built in Rzeszów due to the rapid increase in the number of cars, be located in the historical part of the city? source: own study

\begin{tabular}{|l|c|c|}
\hline Decyzja & L. & \% \\
\hline Tak & 76 & 40,21 \\
\hline Nie & 97 & 51,32 \\
\hline Nie mam zdania & 16 & 8,47 \\
\hline
\end{tabular}

Jednym z wiodących haseł promujących miasto, jest przedstawianie Rzeszowa, jako ośrodka innowacyjnego. W związku z tym, jedno z pytań kwestionariusza brzmiało: W oparciu o wtasne obserwacje, jak Pan(i) uważa, czy Rzeszów jest miastem innowacji $w$ dziedzinie rozwiazań architektonicznych i urbanistycznych? Podsumowanie udzielonych odpowiedzi zawiera Tabela 10. 
Tabela 10. Rozkład odpowiedzi na pytanie: W oparciu o własne obserwacje, jak Pan(i) uważa, czy Rzeszów jest miastem innowacji $w$ dziedzinie rozwiązań architektonicznych i urbanistycznych? źródło: opracowanie własne

Table 10. Responses to the question: Basing on your own observations do you think that urban and architectural solutions implemented in Rzeszów are innovative? source: own study

\begin{tabular}{|l|c|c|}
\hline Decyzja & L. & \% \\
\hline Tak & 74 & 39,15 \\
\hline Nie & 81 & 42,86 \\
\hline Nie mam zdania & 34 & 17,99 \\
\hline
\end{tabular}

W dalszej kolejności respondenci wyrażali swoją opinię na temat tego, czy zachowany autentyzm oblicza zabytkowego miasta powinien być chroniony przed projektami nowoczesnej zabudowy. Rozkład odpowiedzi zebrano w Tabeli 11.

Tabela 11. Rozkład odpowiedzi na pytanie: Czy - Pana(-ni) zdaniem - zachowany autentyzm oblicza zabytkowego miasta powinien być chroniony przed projektami nowoczesnej zabudowy? źródło: opracowanie własne

Table 11. Responses to the question: Do you take the view that saved, original nature of the historical part of the city should be protected against modern development projects? source: own study

\begin{tabular}{|l|c|c|}
\hline Decyzja & L. & \% \\
\hline Tak & 99 & 52,38 \\
\hline Nie & 66 & 34,92 \\
\hline Nie mam zdania & 24 & 12,70 \\
\hline
\end{tabular}

Kolejne pytanie kwestionariusza brzmiało: Czy jest Pan(i) za utrzymaniem zwyczajowo przyjmowanej roli ulic i placów, jako aktywnych przestrzeni spotecznych, w nowo projektowanych kwartatach miasta? Podsumowanie udzielanych odpowiedzi zawarto w Tabeli 12.

Tabela 12. Rozkład odpowiedzi na pytanie: Czy jest Pan(i) za utrzymaniem zwyczajowo przyjmowanej roli ulic i placów, jako aktywnych przestrzeni społecznych, w nowo projektowanych kwartałach miasta? źródło: opracowanie własne

Table 12. Responses to the question: Are you of opinion that customary accepted role of streets and squares perceived as active social spaces should be kept in new-designed quarters of the city? source: own study

\begin{tabular}{|l|c|c|}
\hline Decyzja & L. & \% \\
\hline Tak & 146 & 77,25 \\
\hline Nie & 10 & 5,29 \\
\hline Nie mam zdania & 33 & 17,46 \\
\hline
\end{tabular}


Następnie respondenci byli proszeni o dokonanie oceny wymienionych obiektów Rzeszowa, pod względem ich funkcjonalności, formy architektonicznej i zharmonizowania $\mathrm{z}$ otoczeniem. Wszystkie obiekty powstawały w mieście w czasie ostatnich pięciu lat. Ocena była dokonywana na 5-cio stopniowej skali, gdzie 1 oznaczało ocenę najniższą, a 5 - najwyższą. Średnie uzyskanych wyników zestawiono w Tabeli 13.

Tabela 13. Średnie ocen wybranych obiektów Rzeszowa, w aspekcie funkcjonalności, formy architektonicznej i zharmonizowania z otoczeniem, źródło: opracowanie własne

Table 13. Average assessments of Rzeszów's selected buildings appraised in terms of their functionalities, architectural forms and how they blend in with the surroundings, source: own study

\begin{tabular}{|l|c|c|c|}
\hline \multicolumn{1}{|c|}{ Obiekt } & Funkcjonalność & $\begin{array}{c}\text { Forma architek- } \\
\text { toniczna }\end{array}$ & $\begin{array}{c}\text { Zharmonizowanie } \\
\text { Z otoczeniem }\end{array}$ \\
\hline Capital Towers & 3,19 & 3,51 & 2,79 \\
\hline $\begin{array}{l}\text { Budynek Galerii Rze- } \\
\text { szów, Al. Piłsudskie- } \\
\text { go }\end{array}$ & 3,90 & 3,60 & 3,22 \\
\hline $\begin{array}{l}\text { Millenium Hall, Al. } \\
\text { Kopisto }\end{array}$ & 3,81 & 4,08 & 3,58 \\
\hline $\begin{array}{l}\text { Siedziba Urzędu Mar- } \\
\text { szałkowskiego, Al. Ł. } \\
\text { Cieplińskiego }\end{array}$ & 3,58 & 3,55 & 3,67 \\
\hline $\begin{array}{l}\text { Regionalne Centrum } \\
\text { Dydaktyczno- } \\
\text { Konferencyjne Poli- } \\
\text { techniki Rzeszow- } \\
\text { skiej, Al. Powstańców } \\
\text { Warszawy }\end{array}$ & 3,47 & 3,27 & 3,44 \\
\hline $\begin{array}{l}\text { Centrum Mikroelek- } \\
\text { troniki i Nanotechno- } \\
\text { logii Uniwersytetu } \\
\text { Rzeszowskiego, } \\
\text { ul. Pigonia }\end{array}$ & 4,02 & 3,24 & 3,52 \\
\hline $\begin{array}{l}\text { Budynek Sądu Rejo- } \\
\text { nowego, ul. Gen. J. } \\
\text { Kustronia }\end{array}$ & 2,75 & 3,50 \\
\hline
\end{tabular}

Osoby badane ustosunkowywały się również do następującej kwestii - czy mieszkańcy miasta powinni mieć wpływ na formę architektoniczną nowo powstających obiektów na terenie starego miasta (np. wyrażając swoją opinię w badaniach ankietowych)? Rozkład odpowiedzi prezentuje Tabela 14. 
Tabela 14. Rozkład odpowiedzi na pytanie: Czy Pana(-ni) zdaniem mieszkańcy miasta powinni mieć wptyw na formę architektoniczna nowo powstających obiektów na terenie starego miasta (np. wyrażając swoja opinię w badaniach ankietowych)? źródło: opracowanie własne

Table 14. Responses to the question: Do you think inhabitants of the city should have an opportunity to influence architectural form of new buildings to be erected in the Old Town (e.g. presenting their opinions in questionnaires)? source: own study

\begin{tabular}{|l|c|c|}
\hline Decyzja & L. & \% \\
\hline Tak & 117 & 61,90 \\
\hline Nie & 50 & 26,46 \\
\hline Nie mam zdania & 22 & 11,64 \\
\hline
\end{tabular}

Ostatnie pytanie ankiety brzmiało: Jakich nowych inwestycji urbanistycznych $i$ architektonicznych potrzebuje - Pana(-ni) zdaniem - Rzeszów? Odpowiedzi prezentuje Tabela 15.

Tabela 15. Postulowane przez respondentów nowe inwestycje urbanistyczne i architektoniczne w Rzeszowie, źródło: opracowanie własne

Table 15. New urban and architectural investments in Rzeszów proposed by respondents, source: own study

\begin{tabular}{|l|c|}
\hline \multicolumn{1}{|c|}{ Obiekt } & L. \\
\hline Parkingi, parkingi wielopoziomowe, parkingi podziemne & 52 \\
\hline Aquapark, baseny & 44 \\
\hline Zagospodarowanie bulwarów i terenów zielonych dla celów rekreacji & 36 \\
\hline $\begin{array}{l}\text { Rozwiązanie problemów komunikacyjnych, zmniejszenie ruchu samocho- } \\
\text { dowego w centrum }\end{array}$ & 26 \\
\hline $\begin{array}{l}\text { Budowa i modernizacja obiektów sportowych, hala sportowa, centrum } \\
\text { sportu }\end{array}$ & 23 \\
\hline Modernizacja dworców PKP i PKS & 24 \\
\hline Ścieżki rowerowe & 16 \\
\hline Kolejka nadziemna & 14 \\
\hline Budowa obiektów promocji kultury i sztuki & 14 \\
\hline Obwodnice & 13 \\
\hline Obiekty promujące naukę i technikę & 7 \\
\hline Kryte lodowisko & 5 \\
\hline
\end{tabular}




\section{Wnioski}

Respondenci rekrutowali się z różnych grupy wiekowych, przeważała reprezentacja ludzi młodych, do 35. roku życia. Pomimo, że osoby biorące udział $\mathrm{w}$ badaniach nie zawsze stosowały się do cezury czasowej, podanej $\mathrm{w}$ ankiecie (sondaż dotyczył obiektów powstałych w latach 2009-2014), to wyniki badań są godne uwagi, gdyż odnoszą się do architektury Rzeszowa ostatnich lat. Badani bez problemu wymieniali obiekty architektoniczne zaliczane do nowej architektury, co można uznać za pozytywny objaw zainteresowania mieszkańców nowymi inwestycjami na terenie miasta. Podjęli się próby dokonania oceny wybudowanych obiektów pod względem ich funkcjonalności, formy architektonicznej i zharmonizowania $\mathrm{z}$ otoczeniem. Średnie wyniki tych ocen mieszczą się w granicach 3.19 a 3.89. Najniżej oceniono funkcjonalność nowej architektury, a najwyższa ocenę uzyskata forma architektoniczna. Posługując się skalą ocen od 1 do 5, należy przyjąć, że nowe inwestycje w opinii mieszkańców zrecenzowane zostały na poziomie nieco powyżej średniej.

Natomiast za symbol rozwoju miasta uznana została ktadka nad ul. J. Pitsudskiego, uzyskując największą ilość punktów. Wybór ten uzasadniony został m.in.: interesującą i intrygującą funkcją, nowoczesnością, nowym kierunkiem w usprawnieniu komunikacji. Zdecydowana większość wypowiedziała się za prowadzeniem badań dokumentujących dorobek minionych pokoleń oraz eksponowania ich wyników w obrazach i dziełach materialnych. Respondenci wyrazili swoje negatywne stanowisko $w$ sprawie budowy obiektów powyżej pięciu kondygnacji w zespole starego miasta. Rozwój „organizmu” miasta zdecydowano pozostawić do swobodnego powiększania się. Większość badanych wypowiedziała się przeciwko lokalizacji wielopiętrowych parkingów na terenie zabytkowego miasta. W opinii respondentów Rzeszów nie jest ośrodkiem zasługującym na miano „miasta innowacji” w rozwiązaniach architektonicznych i urbanistycznych. Przewagę otrzymało stanowisko w sprawie zachowania oblicza zabytkowego miasta, przed ingerencja nowoczesnej architektury. Respondenci potwierdzili potrzebę zachowania tradycyjnej roli ulic i placów miejskich, a w związku z tym, odwołali się do tradycyjnej tkanki miejskiej. Niezwykle interesujące okazały się odpowiedzi na pytanie trzynaste. Pod względem funkcjonalności i formy architektonicznej najwyższą ocenę otrzymało Centrum Mikroelektroniki i Nanotechnologii Uniwersytetu Rzeszowskiego. Natomiast pod względem zharmonizowania $\mathrm{z}$ otoczeniem wyższą ocenę otrzymała siedziba Urzędu Marszałkowskiego. Wysoko pod względem funkcjonalności (na drugim miejscu) oceniono budynek Galerii Rzeszów, a pod względem formy architektonicznej - Millenium Hall.

Respondenci wykazali się znacznym zainteresowaniem ochroną sylwety starego miasta Rzeszowa, wskazując na ekspozycję na pierwszym planie obiektów historycznych. Nowa architektura ma wyrastać w tle zabytkowej i być podporządkowana zachowanej skali. $\mathrm{Z}$ pełnym zrozumieniem wypowiedziano się w sprawie prowadzenia badań nad zachowanym wielokulturowym dziedzictwem 
oraz jego ekspozycja. Wynik ten wpisuje się w postawę poszanowania kultur, które stały się podwaliną rozwoju miasta.

Badani mieszkańcy w $62 \%$ byli zgodni, że powinni mieć możliwość wyrażania swojej opinii w sprawie wyboru nowych form architektonicznych w zespole starego miasta. W ostatnim pytaniu wypowiedziano się na temat planowania nowych inwestycji w mieście. Najwięcej, bo ponad połowa badanych, uznała, że w pierwszej kolejności należy inwestować w parkingi, tereny sportowe i rekreacyjne oraz komunikację miejską.

\title{
Literatura
}

[1] Gosztyła M.: Przemiany idei i metod konserwatorskich w latach 1863-2003 na przykładzie zabytków architektury województwa podkarpackiego, Oficyna Wydawnicza PRz, Rzeszów 2006.

[2] Gosztyła M., Gosztyła T., Pasztor P.: Students' opinions and attitudes towards protection and conservation of historical urban architecture of Koszyce, Rzeszów and Jarosław, Transactions of the Uniwersities of Košice, no.4, 2014, pp. 6-20.

\section{MODERN ARCHITECTURE OF RZESZÓW IN RESIDENTS' AND STUDENTS' OPINIONS}

\begin{abstract}
S u m m a r y
The purpose of the study was to examine residents' and students' opinions concerning modern objects and architecture in Rzeszów. In recent years numerous discussions can be seen, concerning maintaining historical values of cities' centers. Inter alia there is a problem of coexistence of modern and historical architecture in the city. In view of the above, another aim of the research was to examine residents' opinions concerning preservation of cultural heritage, discovered in the city. The respondents mentioned the architectonic objects which were built during the last five years and they assessed their architectonic form, function and harmonization of the buildings with the surrounding. The research proved that the inhabitants are interested in new architectonic and urban solutions in Rzeszów, they can assess them in the proposed scale, and they strongly support the preservation of the historical image of the urban complex. In the planned new urban development they support the maintenance of traditional role of the streets and squares. They stand for running research aiming at discovering the common multi-cultural heritage of communities and nations which have lived in Rzeszów for many ages. They accept the modern forms of exhibition of historical architectonic masterpieces. The respondents expressed their criticism with regard to building objects of more than five storeys and multi-storey garages within the city historical complex. As far as the city development scale was concerned, they chose the free development of the municipal centre. The inhabitants surveyed expressed the will to present their position on the modern architecture realized in the place of their residence. Among the future architectonic and construction investments which are essential for the purposes of the city development, communication solutions were underlined.
\end{abstract}

Keywords: Rzeszów, architecture, cultural heritage, public opinion

Przestano do redakcji: 29.01.2016 $r$.

Przyjęto do druku: 1.06.2016 r.

DOI: $10.7862 / \mathrm{rb} .2016 .108$ 